\title{
Integrative characterization of germ cell-specific genes from mouse spermatocyte UniGene library Eunyoung Choi ${ }^{1}$, Jiae Lee ${ }^{1}$, Jungsu Oh${ }^{1}$, Inju Park ${ }^{1}$, Cecil Han ${ }^{1}$, Chongil Yi ${ }^{1}$, Do Han Kim¹, Byung-Nam Cho ${ }^{2}$, Edward M Eddy ${ }^{3}$ and Chunghee Cho*1
}

Address: ${ }^{1}$ Department of Life Science and Research Center for BiomolecularNanotechnology, Gwangju Institute of Science and Technology, Gwangju 500-712, Korea, ${ }^{2}$ Department of Life Science, The Catholic University of Korea, Buchon 421-743, Korea and ${ }^{3}$ Gamete Biology Section, Laboratory of Reproductive and Developmental Toxicology, National Institute of Environmental Health Sciences, National Institutes of Health, Research Triangle Park, North Carolina 27709, USA

Email: Eunyoung Choi - ibbnida@hotmail.com; Jiae Lee - reslee@hanmail.net; Jungsu Oh - tornado94@hanmail.net; Inju Park - seafood0980@hanmail.net; Cecil Han - yakcecil@hanmail.net; Chongil Yi - yici@gist.ac.kr; Do Han Kim - dhkim@gist.ac.kr; ByungNam Cho - ocean@catholic.ac.kr; Edward M Eddy - eddy@niehs.nih.gov; Chunghee Cho* - choch@gist.ac.kr

* Corresponding author

Published: 28 July 2007

BMC Genomics 2007, 8:256

doi:10.1|86/|47|-2164-8-256
Received: 16 March 2007

Accepted: 28 July 2007

This article is available from: http://www.biomedcentral.com/I47I-2/64/8/256

(c) 2007 Choi et al; licensee BioMed Central Ltd.

This is an Open Access article distributed under the terms of the Creative Commons Attribution License (http://creativecommons.org/licenses/by/2.0), which permits unrestricted use, distribution, and reproduction in any medium, provided the original work is properly cited.

\begin{abstract}
Background: The primary regulator of spermatogenesis, a highly ordered and tightly regulated developmental process, is an intrinsic genetic program involving male germ cell-specific genes.

Results: We analyzed the mouse spermatocyte UniGene library containing 2155 gene-oriented transcript clusters. We predict that $11 \%$ of these genes are testis-specific and systematically identified 24 authentic genes specifically and abundantly expressed in the testis via in silico and in vitro approaches. Northern blot analysis disclosed various transcript characteristics, such as expression level, size and the presence of isoform. Expression analysis revealed developmentally regulated and stage-specific expression patterns in all of the genes. We further analyzed the genes at the protein and cellular levels. Transfection assays performed using GC-2 cells provided information on the cellular characteristics of the gene products. In addition, antibodies were generated against proteins encoded by some of the genes to facilitate their identification and characterization in spermatogenic cells and sperm. Our data suggest that a number of the gene products are implicated in transcriptional regulation, nuclear integrity, sperm structure and motility, and fertilization. In particular, we found for the first time that $\mathrm{Mm} .3330 \mathrm{I0}$, predicted to contain a trypsin-like serine protease domain, is a sperm acrosomal protein.
\end{abstract}

Conclusion: We identify 24 authentic genes with spermatogenic cell-specific expression, and provide comprehensive information about the genes. Our findings establish a new basis for future investigation into molecular mechanisms underlying male reproduction.

\section{Background}

During male reproduction, germ cells are processed from the primordial stage through spermatogenesis occurring in the seminiferous tubules of testis. The tightly regulated process that occurs in mitotic, meiotic, and post-meiotic phases drives successful male germ cell development or spermatogenesis [1-3]. Spermatogonial stem cells located around the outer region next to the basal lamina sur- 
rounding seminiferous tubules undergo mitosis, and some differentiate into later-stage spermatogonia that gradually become primary spermatocytes. At this stage, the most important event, meiosis, is additionally required. These cells continue through the first meiotic division to become secondary spermatocytes. A second meiotic division occurs in rapid succession to produce haploid spermatids that are remodeled into spermatozoa by spermiogenesis. The tight modulation of this developmental process suggests the expression of a highly organized network of genes. The regulation of gene expression during spermatogenesis occurs at three levels, namely the intrinsic, interactive, and extrinsic levels [3]. The intrinsic program determines which genes are utilized and when genes are expressed in germ cells. The interactive process between germ cells and somatic cells is necessary for germ cell proliferation and progression, and is regulated by extrinsic influences, such as steroid and peptide hormones. Notably, the intrinsic genetic program involves germ cell- and stage-specific gene expression.

Recently, several studies have focused on the identification of cell- and tissue-specific transcriptomes using highthroughput genomics. While earlier studies have provided inclusive information about testicular genes, the identities and characteristics of spermatogenic cell-specific genes are largely unknown [4-9]. The UniGene database contains an extensive collection of information about sets of transcript sequences, including ESTs (Expressed Sequence Tags). UniGene transcripts are organized into clusters composed of fragments of sequences overlapping with at least one other member of the same cluster. GenBank sequences are automatically partitioned into non-redundant sets of gene-oriented clusters [10]. Consequently, each cluster contains sequences corresponding to a single gene, and related information, such as gene expression patterns and mapping positions analyzed in silico. Thus, the UniGene database provides significant information (a combination of gene sequences and computational bioinformatics) to facilitate the prediction of gene expression and function from each cluster.

Comprehensive understanding of male germ cell development and fertilization requires discovery and functional characterization of germ cell-specific genes, because they are highly unique processes that do not occur in any other tissue. Previously, we identified and characterized a number of novel genes from the round spermatid UniGene library [11]. The spermatocyte stage is also a significant period during which meiosis occurs and haploid daughter cells are produced. Here, as an ongoing study on germ cell-specific genes, we identify 24 spermatogenic cell-specific genes, using sequence information from the spermatocyte UniGene database, and analyze their characteristics at the gene and transcript levels. Further, we characterized proteins encoded by the genes and predict that a number of them have significant functions in various processes during spermatogenesis and fertilization. Thus, we report the efficient and unique systematic identification and in-depth characterization of unexplored genes specific to spermatogenic cells.

\section{Results \\ The spermatocyte UniGene library and in silico selection of gene candidates}

The McCarrey Eddy spermatocyte library of mus musculus (Lib.6787), one of the largest spermatogenic cell libraries deposited in the UniGene database at NCBI [12], was analyzed to classify gene entries into known and unknown genes, or testis-specific and non-testis-specific genes. As of April 2006 (Mus musculus UniGene Build \#156), the spermatocyte library consisted of 2155 UniGene entries. We classified the genes from the library on the basis of the following criteria: (i) Genes previously named or assigned with potential functions were classified as 'known', and genes with unassigned functions were regarded as 'unknown'. (ii) If all of ESTs of a given gene were found only in testis and/or spermatocyte, or the numbers of testis or spermatocyte ESTs in a cluster were higher (nine times or more) than that of non-testis and/or spermatocyte ESTs, the gene cluster was selected as 'testis-specific'. According to these criteria, about three-fourth of the genes were classified as known/named, and 112 were testis-specific. On the other hand, we selected 544 clusters as unknown genes, of which 118 were testis-specific (Table 1). Although three quarters of the total gene entries are named/known genes, similar numbers of testis-specific genes were found among the known and unknown candidates, indicating that many of the testis-specific genes remain to be characterized. Taken together, the combina-

Table I: Classification of genes in the spermatocyte library

\begin{tabular}{lc}
\hline Genes & Number \\
\hline Total entries (as of Aril 2006) & 2155 \\
Known (named) & 1611 \\
Testis specific & 112 \\
Unknown & 544 \\
Testis specific & 118 \\
Total entries (as of March 2003) & 1218 \\
Unknown, testis specific & 134 \\
Analyzed in vitro & 81 \\
Authentic, testis specific & 24
\end{tabular}

Gene entries from the spermatocyte UniGene library were classified into known and unknown genes, or testis-specific and non-testisspecific genes. Genes with $>90 \%$ testicular ESTs of total ESTs, including three non-testicular tissues at most, were classified as testisspecific genes. One hundred thirty four genes selected from the earlier version of the library were analyzed in vitro to determine whether they are authentic genes with abundant and evident testisspecific expression. All of the 134 genes are listed in Table 2. 
tion of known and unknown testis-specific genes comprises $11 \%$ of the spermatocyte UniGene entries.

At the beginning of our study (March 2003), the total number of gene entries within the earlier version of the spermatocyte library was 1218 . A search for testis-specific genes with unknown or unassigned functions resulted in the selection of 134 candidates and these genes were further analyzed in the present study (Tables 1 and 2).

\section{Testicular expression of genes}

To determine whether the candidates selected from the UniGene library are true genes with testis-specific expression, various analyses were performed (Table 2). In total, 134 gene candidates were analyzed with regard to whether their open reading frames contained reliable amino acid coding regions. We regarded a certain gene candidate as a gene with a reliable amino acid coding region if the size of the longest coding sequence is larger than at least $20 \%$ of that of an entire transcript (mRNA) sequence in the gene. Of these, 81 genes encoded possible amino acid sequences, while remaining 53 candidates showed that deduced coding sequences are too short, compared to transcript sizes (i.e., A deduced coding region comprises less than $20 \%$ of an entire transcript sequence), or displayed unreliable coding regions (multiple small coding regions). Accordingly, these 53 genes were eliminated from further analyses. Reverse transcription-polymerase chain reaction (RT-PCR) analysis of the 81 candidates resulted in the amplification of PCR products with the expected sizes in 56 candidates. However, we observed no or incorrectly sized PCR products of the remaining 25 candidates from testes, which were thus excluded from further analysis. Tissue distribution was investigated by PCR using mouse cDNA from eight different tissues. Out of the 56 candidate genes, 37 were identified as testis-specific or predominant (Table 2). Gene expression data from 24 of the 37 genes are shown in Figure 1, since subsequent Northern blot analysis revealed abundant expression only in these genes (see below, and Table 2 and Figure 2). All the gene transcripts were amplified with the correct sizes (Table 3 and Figure 1A), and specifically or predominantly expressed in the testis (Figure 1B). Spermatogenesis occurs in seminiferous tubules containing a mixture of germ cells and somatic cells, such as Sertoli cells. None of the genes were transcribed in germ cell-lacking testes of $W / W^{v}$ mutant mice (Figure 1A).

\section{Transcript analysis of genes}

To determine the expression levels and transcript sizes of the gene candidates, we performed Northern blot analysis (Figure 2). For 24 of the 37 genes, significant signals were detected in total RNA samples from testis, but not those from liver tissue (used as a negative control). These results are consistent with tissue distribution data obtained by
RT-PCR. Testicular transcript sizes ranged from $\sim 1 \mathrm{~kb}$ (Mm.425335) to $7 \mathrm{~kb}$ (Mm.329058). For 17 genes, transcript sizes determined by Northern blotting were comparable to those estimated from the UniGene database, while for the other seven genes, appreciable differences in transcript size ( $>+/-0.5 \mathrm{~kb}$ ) were evident between Northern blots and UniGene database sequences (Figure 2). Thus, the transcript sequences for the 17 genes can be regarded with confidence as full-length cDNAs or sequences containing the majority of entire cDNA sequences. The Northern blot analysis also revealed that four genes produce transcripts with more than a single size (Figure 2), suggesting the presence of multiple transcript isoforms in these genes by alternative splicing.

\section{Developmental expression patterns of genes}

To establish the developmental expression patterns of the 24 genes during spermatogenesis, RT-PCR analysis was performed using mouse testis cDNA obtained at different time-periods after birth (8-84 days). During spermatogenesis in prepubertal mouse, primordial germ cells proliferate and differentiate increasingly to produce spermatogonia, spermatocytes, and spermatids (Figure 3A) [13]. If a particular gene is expressed in germ cells during spermatogenesis, the corresponding transcript will appear in the testis at a post-partum time-point corresponding to the specific stage of spermatogenesis.

RT-PCR data disclosed that all the genes are expressed at least after day 12, indicative of germ cell-specific and developmentally regulated expression (Figure 3B). The 24 genes could be divided into 5 clusters, based on expression patterns. The first cluster, including two genes, is expressed from the early spermatocyte (leptotene and zygotene) stage generated from 12-day-old postnatal mouse testes. The second and third clusters, the pachytene spermatocyte stage, is generated from 14- and 16-day-old postnatal mouse testes, respectively, and contain 16 genes. Two genes comprising the fourth cluster were expressed from the late spermatocyte stage generated from 20-day-old postnatal mouse testes. The fifth cluster involving the spermatid stage contained four genes. It should be noted that the majority of the genes are expressed at the spermatocyte stage from which the genes were selected in silico. Genes encoding ADAM2 (a disintegrin and metalloprotease 2) and protamine 2, of which expression starts during and after meiosis, respectively, were used for controls (data not shown).

\section{In silico analysis of genomic, transcript, and protein characteristics}

To characterize genomic, transcript and protein natures of the genes, we performed various database searches. Figure 4 shows exon organization, chromosomal locations, transcript sizes, numbers of amino acids, specific domain/ 
Table 2: Analysis of unknown, testis-specific gene candidates

\begin{tabular}{|c|c|c|c|c|c|c|c|c|c|c|c|}
\hline \multirow[t]{2}{*}{ No } & \multirow[t]{2}{*}{ ID } & \multirow[t]{2}{*}{ Coding seq. } & \multicolumn{2}{|c|}{ PCR } & \multirow[t]{2}{*}{ Northern } & \multirow[t]{2}{*}{ No } & \multirow[t]{2}{*}{ ID } & \multirow[t]{2}{*}{ Coding seq. } & \multicolumn{2}{|c|}{ PCR } & Northern \\
\hline & & & $E$ & $\mathrm{~T}$ & & & & & $E$ & $\mathrm{~T}$ & \\
\hline I & Mm.46I40 & + & + & - & & 68 & Mm.84572 & + & + & + & + \\
\hline 2 & Mm.I53895 & + & - & & & 69 & Mm.373242 & + & + & + & + \\
\hline 3 & Mm.85000 & + & + & - & & 70 & Mm.84567 & + & + & - & \\
\hline 4 & Mm.6759I & - & & & & 71 & Mm.81022 & + & + & + & - \\
\hline 5 & Mm.425335 & + & + & + & + & 72 & Mm.73639 & - & & & \\
\hline 6 & Mm.45833 & + & + & + & + & 73 & Mm.2907I8 & + & + & + & + \\
\hline 7 & Mm.26987 & + & + & - & & 74 & Mm.66965 & + & + & - & \\
\hline 8 & Mm.232593 & + & + & + & - & 75 & Mm.55870 & + & + & + & + \\
\hline 9 & Mm.I5704I & - & & & & 76 & Mm.50068 & + & + & + & - \\
\hline 10 & Mm.I52558 & + & - & & & 77 & Mm.46472 & - & & & \\
\hline 11 & Mm.I52543 & + & - & & & 78 & Mm.46I59 & + & + & + & + \\
\hline 12 & Mm.I38549 & + & + & - & & 79 & Mm.437I89 & + & + & + & + \\
\hline 13 & Mm. I07775 & + & + & + & + & 80 & Mm.II 6803 & + & + & + & + \\
\hline 14 & Mm.86807 & + & + & + & - & 81 & Mm.46I44 & + & - & & \\
\hline 15 & Mm.8667I & + & + & + & + & 82 & Mm.45824 & + & + & + & + \\
\hline 16 & Mm.6379I & - & & & & 83 & Mm.45377 & + & - & & \\
\hline 17 & Mm.5349 & + & - & & & 84 & Mm.338I0 & - & & & \\
\hline 18 & Mm.I57509 & + & - & & & 85 & Mm.329058 & + & + & + & + \\
\hline 19 & Mm.II 6959 & + & + & - & & 86 & Mm.257647 & - & & & \\
\hline 20 & Mm.8738I & + & + & - & & 87 & Mm.257295 & - & & & \\
\hline 21 & Mm.87368 & + & - & & & 88 & Mm.250945 & + & + & + & - \\
\hline 22 & Mm.85045 & + & + & + & + & 89 & Mm.249832 & + & + & - & \\
\hline 23 & Mm.333010 & + & + & + & + & 90 & Mm.23578 & - & & & \\
\hline 24 & Mm.263708 & + & + & + & + & 91 & $M m .234186$ & - & & & \\
\hline 25 & Mm.72810 & + & + & + & - & 92 & Mm.23377 & + & + & + & + \\
\hline 26 & Mm.67234 & + & + & + & + & 93 & Mm.23356 & + & + & + & - \\
\hline 27 & Mm.660 & + & + & - & & 94 & Mm.233I79 & - & & & \\
\hline 28 & Mm.63782 & + & + & - & & 95 & $M m .230316$ & - & & & \\
\hline 29 & Mm.6II36 & - & & & & 96 & Mm.228I8I & - & & & \\
\hline 30 & Mm.60992 & + & + & - & & 97 & Mm.216973 & - & & & \\
\hline 31 & Mm.56I77 & + & + & + & - & 98 & $M m .210318$ & - & & & \\
\hline 32 & Mm.52285 & + & - & & & 99 & $M m .210312$ & + & + & + & - \\
\hline 33 & Mm.46I24 & + & + & - & & 100 & Mm.|9579I & + & - & & \\
\hline 34 & Mm.45462 & + & + & - & & 101 & Mm.27I248 & - & & & \\
\hline 35 & Mm.33629 & + & + & + & - & 102 & Mm. 165697 & + & + & + & + \\
\hline 36 & Mm.30958 & + & + & + & - & 103 & Mm.191144 & - & & & \\
\hline 37 & Mm.257958 & + & + & - & - & 104 & Mm. 188575 & + & + & + & - \\
\hline 38 & Mm.250904 & - & & & & 105 & Mm. I76944 & - & & & \\
\hline 39 & Mm.250670 & - & & & & 106 & Mm.I75502 & - & & & \\
\hline 40 & Mm.23826I & + & - & & & 107 & Mm. I 72330 & - & & & \\
\hline 41 & Mm.23534 & + & + & + & + & 108 & Mm. 172329 & - & & & \\
\hline 42 & Mm.2I03II & + & - & & & 109 & Mm. I72326 & - & & & \\
\hline 43 & Mm.20109 & - & & & & 110 & Mm. I 72324 & - & & & \\
\hline 44 & Mm. 192428 & + & + & - & & 111 & Mm.17I540 & - & & & \\
\hline 45 & Mm. I8549 & + & - & & & 112 & Mm. I59795 & + & + & + & + \\
\hline 46 & Mm.171269 & + & - & & & 113 & Mm. 159590 & + & + & - & \\
\hline 47 & Mm.I70672 & - & & & & 114 & Mm. 158502 & + & - & - & \\
\hline 48 & Mm. I59587 & - & & & & 115 & Mm. I58267 & + & + & + & - \\
\hline 49 & Mm.I5788I & - & & & & 116 & Mm.I58I64 & + & - & & \\
\hline 50 & Mm.I57632 & + & - & & & 117 & Mm. 157767 & + & + & + & + \\
\hline 51 & Mm. I53685 & + & - & & & 118 & Mm. 157538 & - & & & \\
\hline 52 & Mm. I52610 & - & & & & 119 & Mm.15753। & - & & & \\
\hline 53 & Mm. I52605 & + & + & - & & 120 & Mm.1575I0 & - & & & \\
\hline 54 & Mm.I52599 & + & + & - & & 121 & Mm. 157006 & - & & & \\
\hline 55 & Mm. I52597 & + & - & & & 122 & Mm.1526II & - & & & \\
\hline 56 & Mm.I52594 & - & & & & 123 & Mm. 152606 & - & & & \\
\hline 57 & Mm. I5928I & + & + & + & + & 124 & Mm. 152604 & - & & & \\
\hline 58 & Mm.I52587 & + & - & & & 125 & Mm.15260I & - & & & \\
\hline 59 & Mm.I52586 & - & & & & 126 & Mm. 152600 & + & - & & \\
\hline 60 & Mm.I52544 & - & & & & 127 & Mm.I52598 & + & - & & \\
\hline 61 & Mm.252733 & + & + & + & + & 128 & Mm.I5254I & - & & & \\
\hline 62 & Mm. I4882I & + & - & & & 129 & Mm. I39088 & - & & & \\
\hline 63 & Mm. I $28 \mid 20$ & - & & & & 130 & Mm. I 32427 & - & & & \\
\hline 64 & Mm.II0I4 & - & & & & $|3|$ & Mm. 109314 & + & - & & \\
\hline 65 & Mm. I09877 & - & & & & 132 & Mm.108732 & - & & & \\
\hline 66 & Mm.101915 & + & - & & & 133 & Mm. 103240 & - & & & \\
\hline 67 & Mm.99172 & - & & & & 134 & Mm.1017I7 & - & & & \\
\hline
\end{tabular}

Gene candidates were subjected to in silico and in vitro analyses. Genes with potential coding sequences were analyzed by RT-PCR in which those expressed (E) as correctly-sized PCR products were further analyzed to determine whether they are testis-specific $(T)$. Lastly, to investigate transcript size and expression level, genes with testis-specific expression were subjected to Northern blot analysis. Genes with positive and negative results are indicated as + and - , repectively. 

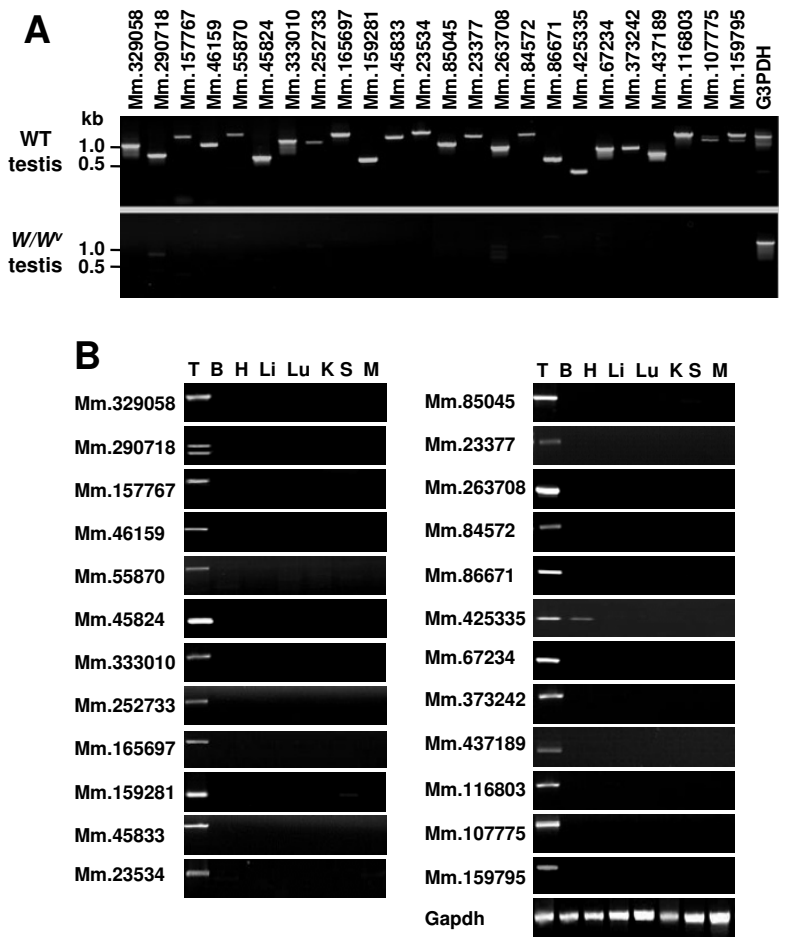

Figure I

Testicular expression of the genes. (A) Complementary DNA from whole testes of wild-type (WT) mice and germ cell-lacking testes of $W / W^{\vee}$ mutant mice were amplified by PCR. All the genes were expressed in wild-type testis but not testis deficient in germ cells, suggesting germ cell-specific expression. The faint bands observed in the germ cell-lacking testes for some of the genes are likely to be non-specific signals, since their sizes are different from those shown in WT testis. (B) Genes were analyzed by RT-PCR in eight adult male mice tissue types. All genes except Mm.425335 were exclusively expressed in the testis. The glyceraldehyde-3phosphate dehydrogenase (Gapdh) band intensity was used to estimate equivalent amounts of cDNA templates among tissues. T, Testis; B, Brain; H, Heart; Li, Liver; Lu, Lung; K, Kidney; S, Spleen; M, Skeletal muscle.

motif, and gene ontology of the predicted proteins encoded by the genes. The exon numbers in the genes are variable, ranging from 1 to 27 exons. The novel genes are widely distributed on mouse chromosomes. To extend these findings on mouse genes, we searched the human genome database for orthologs. Human orthologs for 13 mouse genes were present in genomic regions of conserved synteny between mice and humans. The other 11 genes did not have human orthologs, suggesting differential expansion in the mouse genome. The protein-coding region of each gene was defined by selecting the longest amino acid sequence terminating before a polyadenylation signal (if there is one present), and deduced amino

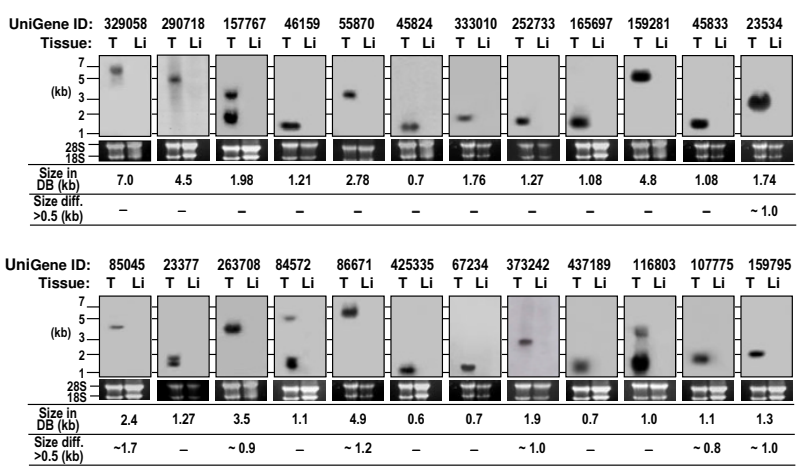

\section{Figure 2}

Transcript analysis of the 24 genes. Total RNA from adult testis $(T)$ and liver $(L)$ was hybridized with cDNA probes of the 24 genes. Agarose gels were stained with ethidium bromide to visualize $28 \mathrm{~S}$ and I8S RNA. Seven genes display significant differences in transcript size between Northern blots and those predicted from the UniGene database (DB). Transcript sizes from known sequences (UniGene database), and transcripts with significant differences in size between the Northern blots and cDNA sequences are indicated below the blots.

acid sequences were subjected to database searches. Nineteen gene products were predicted to contain various domains and motifs, and found to be annotated with gene ontology codes. Thus, based on the in silico information, some of these proteins are predicted to be implicated in transcriptional regulation and/or nuclear activity (Mm.290718, Mm.157767, Mm.85045, Mm.86671 Mm.373242, Mm.437189 and Mm116803), metabolic processes (Mm.46159, Mm.55870, Mm.333010, Mm.252733, Mm86671 and Mm.159795) and cell structure (Mm.45833 and Mm.23534) (Table 4).

\section{Subcellular localization of the proteins}

To explore protein characteristics in vitro, we investigated subcellular localization of the gene products [14]. GFPtagged full-length gene sequences were transiently transfected into GC-2 cells. GC-2 cells are immortalized germ cells (spermatocytes) of mouse testis [15]. We observed GFP signals from 14 out of the 24 gene products analyzed. By contrast, the GFP signals were not detected in the other 10 genes, suggesting that the expression of these proteins is highly transient, very low in amount or delayed. Figure 5 depicts the subcellular locations identified. Five gene products were found to be localized in the nucleus. Other gene products localized to the endoplasmic reticulum (three genes), Golgi apparatus (three genes), and cytoplasm (three genes). It should be noted that the three genes with cytoplasmic localization displayed a speckled localization pattern (Figure 5). The localization data support results from in silico prediction (Mm.290718, 
Table 3: List of genes and gene specific primers designed for RT-PCR analysis

\begin{tabular}{|c|c|c|c|c|}
\hline \multirow[t]{2}{*}{ UniGene ID } & \multirow[t]{2}{*}{ GenBank ID } & \multicolumn{2}{|l|}{ PCR primers } & \multirow[t]{2}{*}{ Size (bp) } \\
\hline & & Forward (5'-3') & Reverse (5'-3') & \\
\hline Mm.329058a & $\mathrm{AB} 097085$ & AAGGCTTCTCTGTCGGATCG & TGCACTCCAGGTTCAAACAG & 797 \\
\hline Mm.2907/8a & DQ864732 & TTGCAAGACTAGGGATGGTG & TGCCAGAGAGTGTGAGAGGG & 588 \\
\hline Mm.157767 & $\underline{\mathrm{AK} 077190}$ & АСTGTACСTGCTGTGACTGC & TTTGTGTTCAGGGTCTCCAG & 979 \\
\hline Mm.46I59a & AK005850 & CTGCAAGTTCCTGTGTTCTG & CAGGGATGACAAGGACAACG & 767 \\
\hline Mm.55870 & AK029548 & TTCTCAGGCTTCCAGGTATG & GGGAGCAAGCCAGTAAGCAG & 1025 \\
\hline$M m .45824^{a}$ & $\overline{\mathrm{AK} 005610}$ & GTCCСTCTGTAAGTCTGAAG & TGGACACTCTTTGGACACAG & 538 \\
\hline Mm.333010 & $\overline{\mathrm{AK} 030264}$ & GATTGCGACAGTTGACAGTG & TGATCCATTGTACAGACGGC & 862 \\
\hline Mm.252733 & AK006257 & GCCGTGATCTCCAAAATGTC & ACAGCTTCAGTGCGTTCTTC & 810 \\
\hline Mm. 165697 & AK006079 & GGCTTTAGTGAGGACCTTGG & ACAGTCCCTAGCTCAGATTG & 968 \\
\hline Mm.15928I & $\overline{X M \quad 127913}$ & TAACGGGAAGAAGGTGGAAG & AGGAGGGTCTGTAAGGTAGC & 475 \\
\hline Mm.45833a & NM 133711 & AGATTGTTTACCACTGCCGG & СТАСTTССТССАТGTССTTC & 914 \\
\hline Mm.23534a & AK016718 & TTCCTCACGGCACAACTCAG & GTGTCCTCCGAATCCCTCAG & 997 \\
\hline Mm.85045 & AK019748 & ССTGTATCTTCACTGCCTCG & AGTTCTCGTTTCAGCCAGGG & 772 \\
\hline Mm.23377a & AF522069 & CCCTAGAGCTCTGTCCTTGG & CAGACATCAGCTCGGCCAAC & 997 \\
\hline Mm.263708 & AK006048 & TCTCGGGCATCCTTCTGGGC & GGCTGAGAAGGTGTGGGCG & 681 \\
\hline Mm.84572 & AK006488 & CCTTTTGGGGTGCACTTGGC & AGAGAGACAACCAAGTGAGC & 1014 \\
\hline Mm.8667I & AKI33200 & TTAAGTCCTGCTGCTGTTGG & ATGCCTCAAGGGAACTCCAG & 440 \\
\hline Mm.425335 & AK005943 & TTCTTTCTCAGGTGCCGATG & CTTTCTGTGACATGTGACGC & 254 \\
\hline Mm.67234 & $\underline{\mathrm{AK} 018916}$ & AAGATGTCCTGTGGCCCTGG & GCCAGACAGAACAGGTAGTG & 639 \\
\hline Mm.373242 & AK077102 & CAGCATAGGCGCAGAAAGAG & AGTCCCAGAGAAGAGGCCAG & 683 \\
\hline Mm.437189a & AF46350I & CTATGACTCGGGTGGCCAAG & TGGCTTTGACAGGACCACAG & 545 \\
\hline Mm. II6803a & $\overline{\mathrm{AKO} 014971}$ & СТСТСТСАССТССGTTCCAG & GAGTGAGAAAGGCAAGGAAG & 1009 \\
\hline Mm. 107775 & AK0I5444 & САTCTGCTCTGGTCCTGCTG & GACAACCCCATTCTATCCCG & 876 \\
\hline Mm.159795a & AK0I4942 & TCGGGCTCACTGTTTGCTAC & TGAAGGAGAGACTAGTGCTG & 964 \\
\hline
\end{tabular}

a The following genes were named previously: Mm.329058, Tudor domain containing 6 (Tdrd6) [47]; Mm2907I8, Zinc finger protein 54I (Zfp54I); Mm.46159, Ring finger protein (Rnfl5I); Mm.45824, Spermatogenesis associated 19 (Spata 19); Mm.45833, Spermatogenesis associated 4 (Spata4) [48]; Mm.23534, Tektin 3 (Tekt3) [23]; Mm.23377, Testis expressed gene 22 (Tep22) [22]; Mm.437189, Cysteine-rich perinuclear theca protein 4 (Cypt4) [20]; Mm I 16803, HRAS-like suppressor family, member 5 (Hrasls5); and Mm. 159795, Cation channel, sperm associated 3 (CatSper3) [2I].

Mm.86671, Mm.373242, Mm.437189 and Mm.159795) and further protein analysis (see below).

\section{Characterization of the proteins in mouse spermatogenic cells and sperm}

To further explore the characteristics of proteins encoded by the genes, we generated antibodies against five proteins (Mm.333010, Mm.23534, Mm.23377, Mm.425335 and Mm.116803). Initially, we attempted to generate antibodies to all the proteins, using GST recombinant proteins and synthetic peptides corresponding to the proteins. However, for the other 19 genes, the recombinant proteins were not expressed in a bacterial system or antisera from rabbits immunized with the antigens did not detect corresponding proteins from testis. The antibodies to the five proteins detected distinctive bands in the extracts of human embryonic kidney (HEK) cells transfected with the corresponding cDNA sequences, but not in those of cells transcfected with the empty vector (Figure 6A). We examined the presence and localization of five proteins from total protein extracts of testicular spermatogenic cells, testicular sperm or mature sperm from cauda epididymis by Western blot analysis (Figure 6B). All the antibodies rec- ognized distinct bands in testicular spermatogenic cells. They were of the sizes comparable with those predicted from the cDNA sequences. Two of the proteins (Mm.425335 and Mm.116803) were present in testicular sperm, but not mature sperm. The other three proteins (Mm.333010, Mm.23534, and Mm.23377) were identified in both testicular and mature sperm. Size differences for Mm.23534 and Mm.23377 were evident between testicular spermatogenic cells, testicular sperm and mature sperm, indicating that these proteins undergo changes during sperm development and maturation (see Discussion). To further establish the subcellular localization of the three proteins in mature sperm, cell surface biotin labeling was performed (Figure 6B). If a certain protein is present on the cell surface, labeling with biotin results in a change in electrophoretic mobility. However, we observed no changes in mobility of the three proteins in sperm. ADAM2 was included as a reference protein, since it is known to be processed during sperm maturation and located on the sperm surface. Taken together, our results provide evidence on the localization of these five proteins, both at the developmental stage level (three proteins present at all stages, and the other two restricted to testic- 


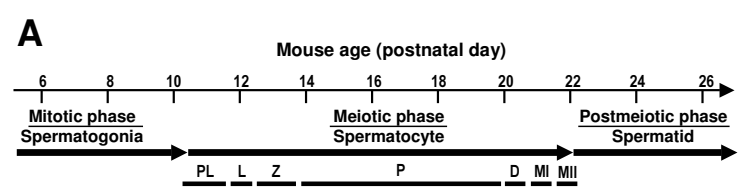

B

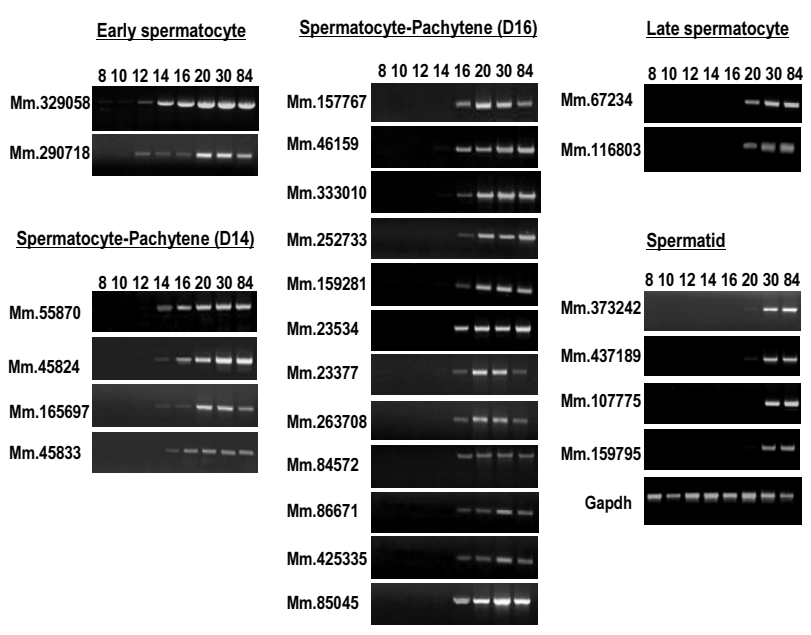

Figure 3

Developmental expression pattern of the genes during spermatogenesis. (A) Schematic diagram of juvenile spermatogenesis composed of mitotic, meiotic and postmeiotic phases. Meiotic prophase includes preleptotene (PL), leptotene $(L)$, zygotene $(Z)$, pachytene $(P)$ and diplotene $(D)$ stages. Spermatocytes at diplotene undergo rapid meiotic divisions (MI and MII). (B) Gene expression was analyzed by RT-PCR using cDNAs prepared from mouse testis at different days after birth. Genes were divided into five groups based on their expression timing. Gapdh, glyceraldehyde-3phosphate dehydrogenase.

ular cells and testicular sperm) and cellular level (three proteins present in an intracellular compartment) in sperm.

To confirm and further examine the developmental expression and localization of the five proteins in spermatogenic cells or mature sperm, we performed indirect immunofluorescence analysis in paraffin sections of adult mouse testis with the antibodies. The antibodies to four proteins, corresponding to Mm.333010, Mm.23534, Mm.425335 and Mm.116803, displayed immunoreactivity in spermatocytes and spermatids (Figure 7A). We were unable to observe signals in testis sections incubated with the antibody to the other protein (Mm.23377). In particular, Mm.333010 was observed in acrosomes of round spermatids, while Mm.23534, Mm.425335 and Mm116803 were identified in the cytoplasmic region located to the posterior of elongating spermatids (Figure
7A). Since the Western blot analysis demonstrated the presence of Mm.333010 and Mm.23534 in mature sperm (Figure 6), we performed immunofluorescence on mature sperm. Consistent with the result from testis sections, Mm333010 and Mm.23534 were observed in the acrosomal region (Figure $7 \mathrm{~B}$ ) and flagellum (Figure $7 \mathrm{C}$ ) of mature sperm, respectively. It is important to note that Mm.333010 is predicted to have a trypsin-like serine protease activity (Figure 4). Table 4 summarizes putative reproductive functions of eight genes with both predicted in silico information and supporting in vitro protein data obtained in this study (see Discussion).

\section{Discussion}

Previously, several studies have investigated genes expressed at specific stages or in particular cell type during spermatogenesis [4-9]. Although these studies provided inclusive information about the expression profile of a large number of germ-cell genes, comprehensive understanding of spermatogenesis requires further systematic identification and analysis of uncharacterized genes with germ cell-specific expression. UniGene is a large and widely used transcript sequence database containing a large amount of unexplored information about genes. The sequences are divided according to tissue type or developmental stage from the UniGene database, which provides a resource for identifying novel tissue-, cell-, or stage-specific gene transcripts. In the present study, analyzing the mouse spermatocyte UniGene library (Lib.6787), we disclosed that significant proportion (11\%) of the spermatocyte genes are testis-specific and about half of the testisspecific genes are unknown or uncharacterized. Previously, a similar approach was applied by our group using the round spermatid UniGene library [11], revealing that $22 \%$ (467 of 2124 genes) of genes expressed in round spermatids are testis-specific and functions of $74 \%$ of the testis-specific genes are unexplored. In the present investigation, the initial number of uncharacterized, testis-specific genes selected from the earlier version of the spermatocyte library is 134 . These 134 genes were narrowed down to 24 authentic genes considered to be abundantly and specifically expressed in the testis by various expression analyses. The other 110 genes were eliminated from consideration because they displayed unreliable coding sequences (53 genes), were undetected or detected with unexpected sizes in the PCR assay (25 genes), not specifically or predominantly expressed in the testis (19 genes) or undetected in the Northern blot analysis (13 genes).

Our data provide extensive information on the 24 genes at the genomic and transcript levels. Genomic analysis disclosed orthologues for 13 mouse genes in the human genome and 11 other were identified as mouse-specific genes. The proportion of mouse genes with a single iden- 


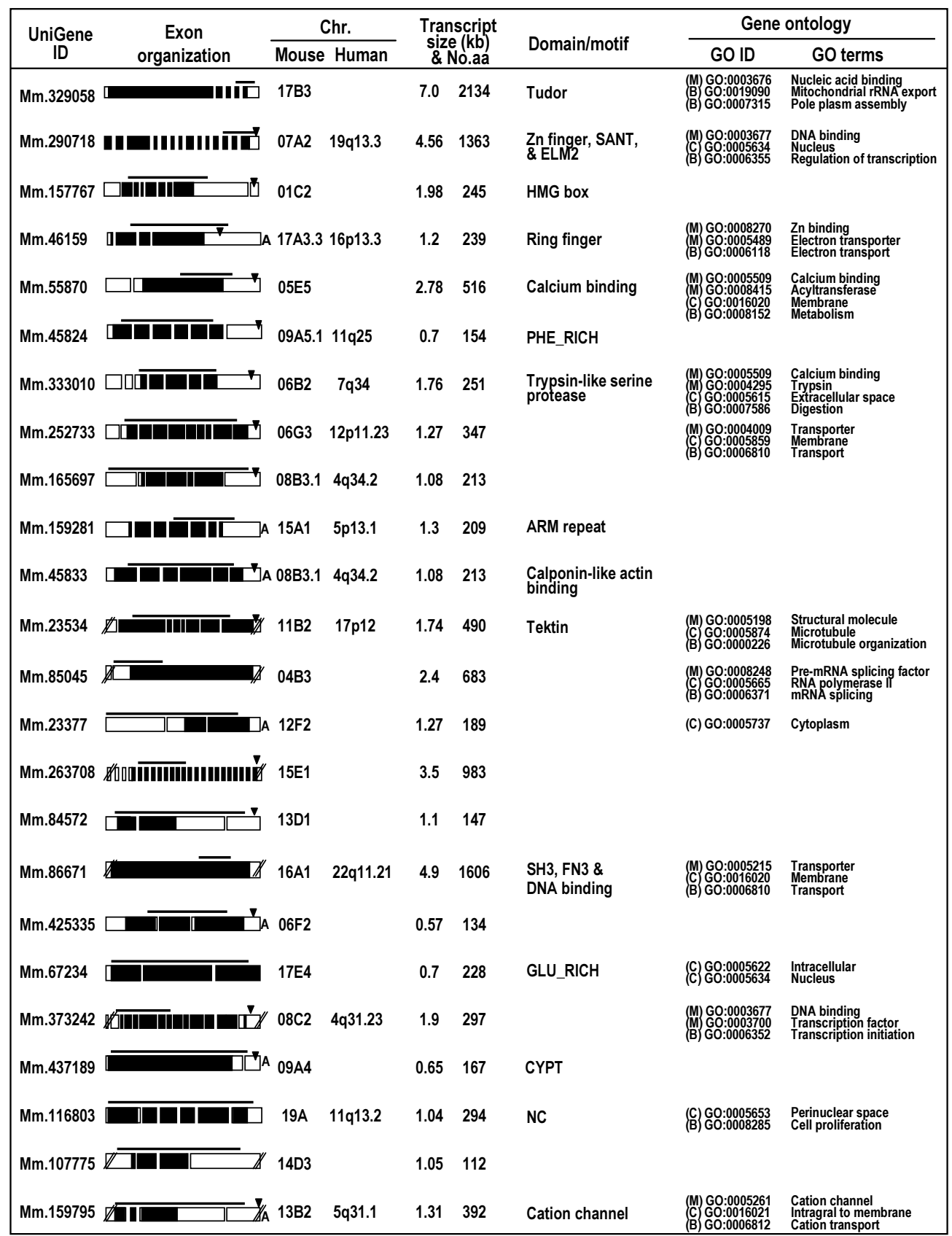

\section{Figure 4}

Genomic, transcript, and protein characteristics of the genes in silico. Gene structure and exon organization were determined using genome database searches. In exon organization, the boxes represent exons. The bars indicate regions amplified in the PCR analysis and used as probes in the Northern blot analysis. Coding regions were determined by selecting the longest open reading frames deduced from cDNA sequences. The predicted coding regions are shaded. The position of the poly $A$ signal is marked by filled arrowheads, and the presence of poly $A$ is indicated by ' $A$ '. Chromosomal location was determined by searching the mouse and human genome databases. The predicted amino acid sequences of genes were analyzed using various bioinformatics tools (see Experimental Procedure). For annotation of genes with ontology terms, amino acid sequences were submitted to and subsequently obtained from exclusive web servers (Goblet), which use a variety of different protein databases and provide gene ontology codes. Each gene ontology code falls into one of the larger categories of molecular function (M), cellular component (C), or biological process (B). 
Table 4: Putative functions of the eight gene products in reproduction

\begin{tabular}{|c|c|c|c|c|c|}
\hline Function & UniGene & In silico information & Localization in GC-2 cells & Presence in TSC & Presence in MS \\
\hline \multirow[t]{3}{*}{ Transcriptional regulation } & Mm.2907I8 & Transcription & $\mathrm{Nu}$ & n.d. & n.d. \\
\hline & Mm.8667I & DNA binding & $\mathrm{Nu}$ & n.d. & n.d. \\
\hline & Mm.373242 & Transcription & $\mathrm{Nu}$ & n.d. & n.d. \\
\hline Nuclear integrity & Mm.437I89 & Perinuclear protein & $\mathrm{Nu}$ & n.d. & n.d. \\
\hline \multirow[t]{3}{*}{ Sperm structure or motility } & Mm.23534 & Tektin3 & Cy & + & $+(\mathrm{T})$ \\
\hline & Mm.23377 & Tep22 & n.d. & + & + \\
\hline & Mm.159795 & CatSper3 & ER & n.d. & n.d. \\
\hline Fertilization & Mm.333010 & Trypsin-like serine protease & GA & + & $+(\mathrm{A})$ \\
\hline
\end{tabular}

Eight genes with in vitro protein data (Figs. 5, 6 and 7) which support in silico information (Table I and Figure 4) are functionally categorized. Abbreviations are as follows: TSC, testicular spermatogenic cells; MS, mature sperm; Nu, nucleus; Cy, cytoplasm; ER, endoplasmic reticulum GA, Golgi apparatus; n.d., not determined; (T), tail; (A), acrosome.

tifiable ortholog in the human genome is about $80 \%$. The other $20 \%$ of mouse genes lack a strict 1:1 relationship, due to differential expansion in at least one of the two genomes [16]. Mostly, those mouse-specific genes were involved in reproduction, olfaction and immunity. Similarly, a global view of human and mouse proteases revealed that the mouse degradome is more complex, and several genes in the mouse genome encode proteases involved in reproductive functions [17]. One such example is the testis-specific or predominant ADAM genes in postmeiotic germ cells [18]. Thus, the 11 mouse-specific genes identified in our study are related to aspects of reproductive physiology. At the transcript level, the Northern blot analysis revealed that four genes are transcribed into products of more than one size. In addition, the analysis demonstrated that transcript sizes from the database are consistent with those determined experimentally for most of the genes. A special feature of genes whose expression is strongly favored in male germ cells is developmentally regulated during meiotic and postmeiotic phases [1,2]. Consistently, the expression patterns of the 24 genes during postnatal testicular development, found in the present study, are indicative of developmental regulation. The pachytene spermatocyte stage is significant during spermatogenesis. It involves genetic recombination, which occurs only in germ cells through cross-over between paired chromosomes and increases RNA and protein synthesis in preparation for the next phase [19]. Transcription of more than half (16 genes) the total genes was found to start from the pachytene spermatocyte stage.

Germ cell-specific and developmentally regulated genes could be directly responsible for the spermatogenesis or fertilization. We also investigated the genes at the protein and cellular levels, providing functional perspectives of the genes. The proteins encoded by 14 out of the 24 genes were analyzed in living GC-2 cells. No expression of the other 10 genes might be due to their peculiar protein natures, such as instability, translational delay and toxic- ity to the cells. Cellular localization of the 14 genes was divided into nucleus, endoplasmic reticulum, Golgi apparatus, and cytoplasm. To further gain an insight into the characteristics of the proteins, we generated antibodies to five proteins. The Western blot analysis disclosed that two proteins were restricted to testicular spermatogenic cells and testicular sperm, while the others were present at all stages, including testicular spermatogenic cells, testicular sperm, and mature sperm. Results from the immunofluorescence analysis of testis sections and mature sperm corroborate and extend the Western blot data. Taken together, our transfection and immuno-analyses provided new information about 16 genes at the protein and cellular levels (Figs. 5, 6 and 7).

Among the 16 genes with the in vitro data, eight genes have in silico information congruous with the in vitro results (Table 3 and Figure 4). We attempted to categorize these eight genes based on all the in silico and in vitro data, and relate them to potential functions in reproduction (Table 4). Three (Mm.290718, Mm86671 and Mm.373242) of the gene products are likely to be involved in transcriptional regulation. All of these proteins were found to be localized in the nucleus of GC-2 cells transfected with the corresponding cDNAs. Mm.437189, predicted to be present in a perinuclear region, was targeted to the nucleus of GC-2 cells. This protein might be related to nuclear activity or integrity of spermatogenic cells. According to a recent report, Mm.437189 belongs to the cysteine-rich perinuclear theca family with potential functions in the remodelling of the spermatid nucleus [20]. Three of the genes seem to encode proteins implicated in sperm structure and motility. It should be noted that these three genes have been named and reported previously [21-23]. Nonetheless, we did not eliminate them because we have obtained new information about these proteins in this investigation. Mm.23377, named Tep22, has been suggested to be involved in the biogenesis of the acrosome and the midpiece of the sperm tail [22]. Our Western blot analysis 


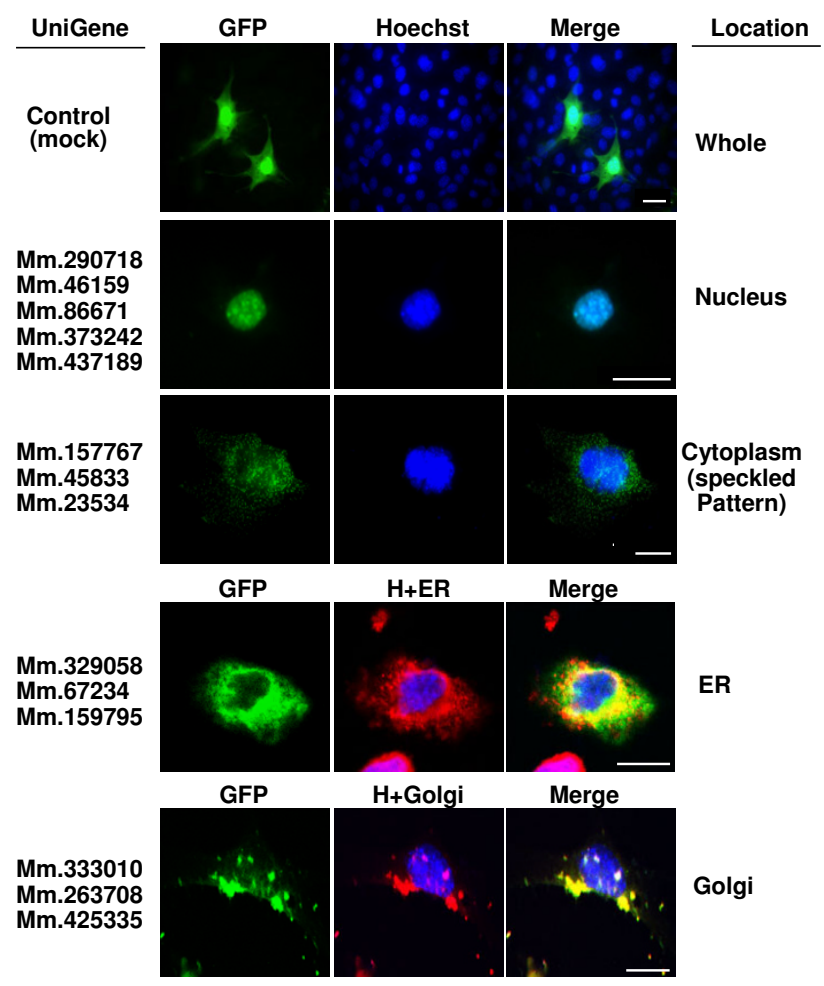

Figure 5

Subcellular localization of the proteins in GC-2 Cells. To determine the subcellular localization of proteins encoded by the 24 genes, GC-2 cells were transfected with each cDNAGFP in turn. Among these, 14 proteins coded by genes were expressed in GC-2 cells. The figure depicts the localization of these 14 genes. Transfected cells were stained with Hoechst 33258 dye (blue), endoplasmic reticulum marker antibody (antibody to protein disulfide isomerase, red) and Golgi apparatus marker (NBD $\mathrm{C}_{6}$-ceramide, red). $\mathrm{H}$, Hoechst; ER, endoplasmic reticulum. Scale bar $=10 \mu \mathrm{m}$.

newly revealed that the Mm.23377 protein made as a 22 $\mathrm{kDa}$-protein in testicular cells is changed to a higher molecular weight form between the stages of testicular sperm and mature sperm, suggesting post-translational modification. Consistent with this, the protein contains several putative glycosylation and phosphorylation sites [22]. Mm.159795, identified as CatSper3 [21], was found localized to the endoplasmic reticulum in GC-2 cells in this study. Other CatSper family members, CatSper1 and CatSper2, are known to be specifically expressed in sperm and linked to sperm motility [24-26]. In fact, the expression pattern of the CatSper3 gene and its essential role in sperm motility and male fertility were reported during the preparation of the present paper $[27,28]$. Mm.23534 has been named Tektin3 which belongs to the TEKTIN family $[23,29-31]$. Tektin 2 and Tektin 4 are microtubule- or outer
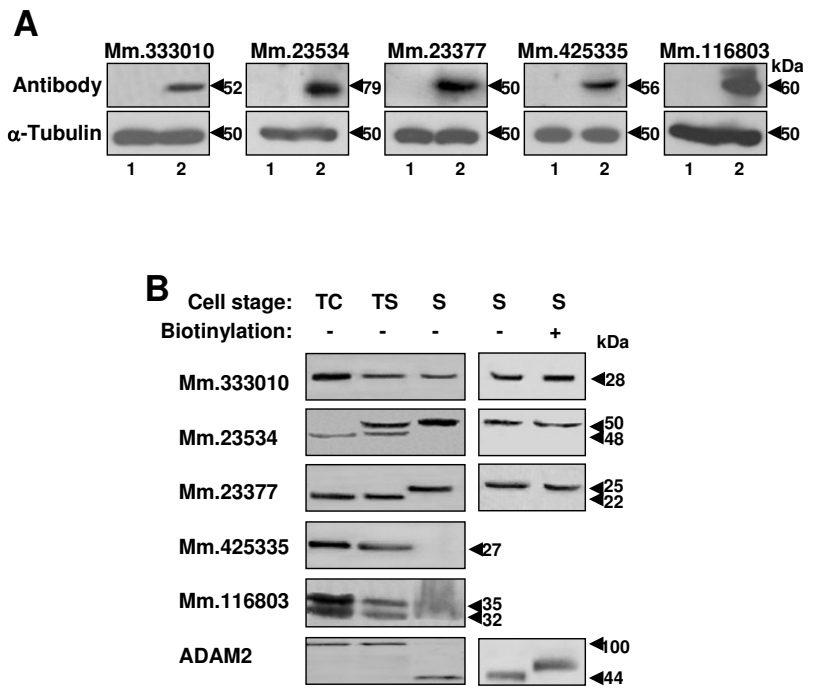

\section{Figure 6}

Western blot analysis of the five proteins. (A) HEK cells transfected with empty vectors (lane I) or GFP-tagged cDNA sequences of the five genes (lane 2) were subjected to Western blot analysis, using antibodies to the proteins. The expected molecular weights of the proteins are $53 \mathrm{kDa}$ (Mm.3330l0), 75 kDa (Mm.23534), 50 kDa (Mm.23377), 52 kDa (Mm.425335), and 57 kDa (Mm.l 16803). An anti-tubulin antibody ( $\alpha$-Tubulin) was used as a control antibody. (B) Protein samples from different stages (testicular spermatogenic cells, testicular sperm, and mature sperm) were blotted with antibodies. Two proteins (Mm.23534 and

Mm.23377) displayed alterations in molecular weight. Among the five proteins, three present in sperm were analyzed with regard to their localization. Mature sperm were treated with biotin $(+)$ or left untreated $(-)$, and subjected to Western blot analysis. ADAM2 was used as a control protein. TC, testicular spermatogenic cells; TS, testicular sperm; S, mature sperm; ADAM, a disintegrin and metalloprotease.

dense fiber-associated proteins in sperm flagella [32,33]. Here, we provide the first information about the Mm23534 protein, Tektin3. This protein was found to be present at the sperm flagella. It should be noted that the molecular size of the Mm23534 protein was increased during spermiogenesis, suggestive of post-translational modification.

Finally, we also obtained original findings on Mm.333010. The protein encoded by Mm.333010 was targeted to the Golgi apparatus in GC-2 cells. The immuno-analysis uncovered that the Mm333010 protein, $28 \mathrm{kDa}$, is present in both spermatogenic cells and mature sperm. In particular, the protein was located in the acrosomal region of mature sperm. It is important to mention that Mm.333010 is predicted to contain a trypsin-like serine protease domain. The acrosome is a Golgi-derived 


\section{A}

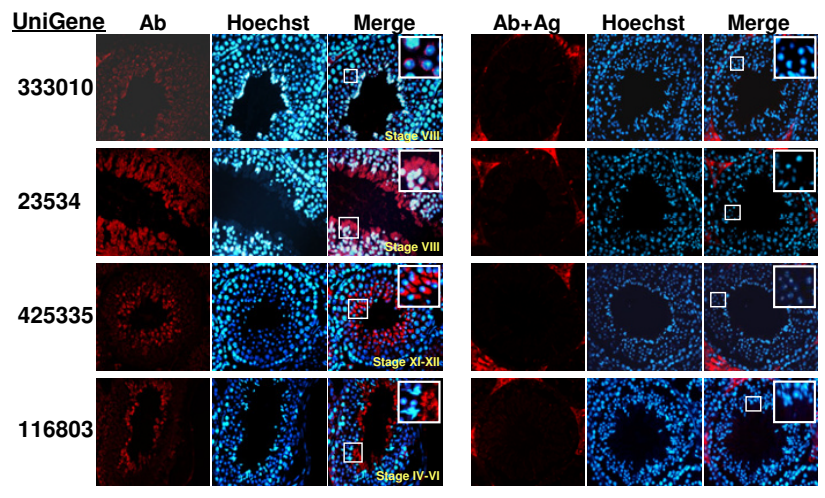

B
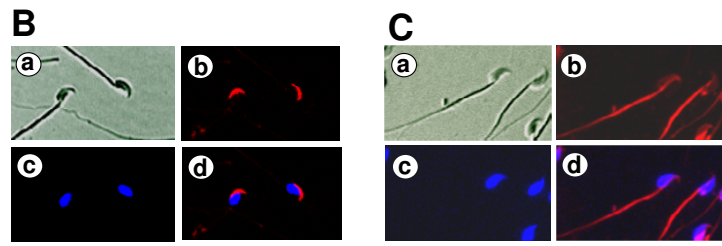

Figure 7

Immunofluorescence analysis of the four proteins. (A) Immunofluorescence staining of paraffin sections of adult mouse testis was performed using specific antibodies for the four proteins (shown at the left). Normal serum was used as the negative control. The red color indicates proteins, and blue color represents nucleus staining by Hoechst. The white rectangular boxes are magnified in the insets in merged images. As a further control, the antibodies were pre-treated with the corresponding antigens and used for immunofluorescence staining (shown at the right). This resulted in the disappearance of the signals in spermatogenic cells. Ab, specific antibody to the proteins; Hoechst, Hoechst staining; Merge, merged images between $\mathrm{Ab}$ and Hoechst; $\mathrm{Ab}-\mathrm{Ag}$, antibodies pre-treated with the corresponding antigens. (B and C) Sperm immunofluorescence using antibodies to two proteins. Mature sperm from cauda epididymis were fixed, pemeabilized and incubated with anti-Mm.333010 (B) or antiMm.23534 (C) antibody. a, transmission image; b, fluorescence image; $c$, Hoechst staining; $d$, merged image between $b$ and $\mathrm{c}$.

secretory granule which is formed during spermiogenesis and positioned at the apex of mature sperm [34]. When sperm reach the egg extracellular coat, the zona pellucida (ZP), during fertilization, they bind to it and undergo acrosome reaction, releasing the acrosomal contents at the site of sperm-egg binding. The hydrolytic and proteolytic enzymes comprising the acrosomal contents digest the ZP and, thus, enable sperm to penetrate the ZP. The sperm acrosome contains both unique enzymes and common enzymes present in somatic cells [35]. To date, only a handful of unique enzymes have been identified and enzymes directly responsible for the fertilization process are unknown [36]. Thus, the Mm.333010 protein is a candidate for a type of protease involved in the penetration of the ZP during fertilization.

\section{Conclusion}

Identification of genes with spermatogenic cell-specific expression is crucial to understanding the molecular basis of spermatogenesis and fertilization. Our in silico analysis indicates that the proportion of testis-specific genes in the spermatocyte UniGene library is $11 \%$ and half of them has been unexplored. We have identified and characterized 24 authentic genes by systematic and integrative approaches, providing insights to their genomic, transcript and protein characteristics. In particular, we predict potential functions of the eight genes, based on our in vitro data as well as in silico information. Thus, the data provided by this study provide a large resource for further investigations into molecular mechanisms of mammalian male reproduction.

\section{Methods RT-PCR}

RT-PCR experiments were performed using cDNA from 8 different tissues (testis, brain, heart, lung, liver, spleen, kidney, and skeletal muscle) of male mouse, as well as cDNA from germ cell-lacking testes of $W / W^{v}$ mutant mice, to determine whether these genes are expressed in somatic cells of testis [37]. To establish specific expression at different stages of spermatogenesis, total RNA obtained from testes of prepubertal and adult male mice (age range 8,10 , $12,14,16,20,30$ and 84 days) was used for reverse transcription. Total RNA extraction was performed using Tri$\mathrm{zol}^{\mathrm{TM}}$ Reagent (MRC) according to the manufacturer's protocol, and cDNA synthesized by random hexamer and oligo(dT) priming with Omniscript reverse transcriptase (Qiagen). Gene-specific primers designed to amplify each region are listed in Table 3. Amplification was performed for 32 cycles of $94^{\circ} \mathrm{C}$ for 30 s, 55,58 or $60^{\circ} \mathrm{C}$ for 30 s, and $72^{\circ} \mathrm{C}$ for $1 \mathrm{~min}$. Primers for glyceraldehyde-3-phosphate dehydrogenase ( $\mathrm{Gapdh}$ ) as a control were employed as follows: forward, 5'-TGA AGG TCG GAG TCA ACG GAT TTG GT-3' and reverse, 5'-CAT GTG GGC CAT GAG GTC CAC CAC-3'.

\section{Northern blot analysis}

Total RNA was isolated from each tissue using Trizol ${ }^{\mathrm{TM}}$ Reagent (Molecular Research Center, Inc.). RNA (10 $\mu \mathrm{g})$ from testis and liver of male mice was heated at $65^{\circ} \mathrm{C}$ for $5 \mathrm{~min}$, and separated on a formaldehyde- $1.2 \%$ agarose gel. The gel was equilibrated for $15 \mathrm{~min}$ in distilled water, and twice for $10 \mathrm{~min}$ in $1 \times$ SSC solution, and total RNA 
was transferred to Hybond-XL membrane (Amersham). The probe was derived from products amplified with gene-specific primers (Table 3 ), and labeled with $[\alpha$ 32P]dCTP (Perkin Elmer) by random priming using the Prime-It kit (Stratagene), according to the manufacturer's protocol. Blots were prehybridized for $30-60 \mathrm{~min}$ at $68^{\circ} \mathrm{C}$ in Rapid-hyb buffer (Amersham), and hybridized for 90 min at $68^{\circ} \mathrm{C}$ in the presence of cDNA probe, following the protocol provided. Blots was washed three times in $2 \times$ SSC/0.05\% SDS at room temperature for $10 \mathrm{~min}$, and twice in $0.1 \times \mathrm{SSC} / 0.1 \% \mathrm{SDS}$ at $68^{\circ} \mathrm{C}$ for $5 \mathrm{~min}$, followed by exposure to Hyperfilm (Amersham) with intensifying screens at $-70^{\circ} \mathrm{C}$.

\section{In silico analysis}

The 24 cDNA sequences were translated into the corresponding peptide sequences, which were analyzed with the diverse computational bioinformatics tools, UCSC [38] and Ensembl [39], to determine intron-exon structures, chromosomal locations, and identify matches with the human chromosomal sequences. Using several computational bioinformatics tools, amino acid sequences deduced from the cDNA sequences of genes were analyzed. PSORT II [40] was applied to predict protein sorting signals, cleavage sites, and intracellular localization. To predict the existence of motifs or domains in translated peptide sequences of genes, CDD [41], Interproscan [42] and PPSearch [43] were employed. SignalP and TMHMM [44] were used to determine the presence of putative signal peptides and transmembrane regions. Goblet [45] was applied to predict gene ontology based on three main classes, specifically, molecular function, biological process and cellular components.

\section{Cell culture and expression of genes fused to GFP}

GC-2 (GC-2spd [ts]) cells were obtained from ATCC (Rockville, MD). Cells were cultured at 5\% $\mathrm{CO}_{2}$ in Dulbecco's modified Eagles medium (DMEM; Gibco) supplemented with $10 \%$ fetal bovine serum at $37^{\circ} \mathrm{C}$. The open reading frames of 24 genes were amplified by PCR, and cloned into the pEGFP-N2 vector (BD Clontech). GC-2 cells were transiently transfected with the gene-EGFP construct using Lipofectamine 2000 (Invitrogen), according to the manufacturer's instructions. At $24 \mathrm{~h}$ after transfection, cells were fixed with formaldehyde, stained with Hoechst 33342 (Sigma), anti-protein disulfide isomerse antibody (Molecular Probes) and NBD $\mathrm{C}_{6}$-ceramide (Molecular Probes), and analyzed for fluorescent signals under the microscope.

\section{Antibodies}

PCR products corresponding to the specific regions of four candidate genes (Mm.333010, Mm.23377, Mm.425335 and Mm.116803) were generated using gene-specific primers designed to add a $5^{\prime}$ BamHI and a 3' EcoRI site.
Following digestion, amplified products were ligated into the corresponding restriction sites of pGEX-5X-2 (Pharmacia). The resulting constructs were expressed in E. coli BL21. Each GST fusion protein was affinity-purified with glutathione Sepharose 4B, except Mm.333010. Four of the purified fusion proteins were used as antigens for the production of a rabbit polyclonal antibody. The GSTMm.333010 fusion protein was highly insoluble. The fusion protein was cleaved, loaded on an SDS-PAGE gel, and employed as an antigen to produce a rabbit polyclonal antibody. All antibodies were purified with the corresponding proteins as antigens and an AminoLink Immobilization kit (Pierce). A synthetic peptide (N-terminal ${ }^{229}$ CLRRIEAHLDKANAQLASDR ${ }^{248}$ of Mm.23534) was used to immunize rabbits. After three immunizations, sera were collected, and polyclonal antibodies purified with the synthetic antigen peptide column using an AminoLink Immobilization kit (Pierce).

\section{Preparation of protein samples}

Testicular cells and sperm were prepared as described [46]. Briefly, the cells are isolated by suspension in 52\% isotonic Percoll (Pharmacia) and centrifugation for 10 min $\left(27,000 \mathrm{~g}, 10^{\circ} \mathrm{C}\right)$, and resuspended in $\mathrm{Mg}^{2+}$-Hepes buffer. Sperm from the cauda epididymis and vas deferens were directly released into PBS. All samples were directly resuspended in $2 \times$ SDS sample buffer, followed by boiling for $5 \mathrm{~min}$, or lysed with a non-ionic detergent (1.0\% NP40) for $1 \mathrm{~h}$ on ice in the presence of protease inhibitor cocktails (CALBIOCHEM). Lysed proteins with a nonionic detergent were centrifuged for $10 \mathrm{~min}$ at $12,000 \mathrm{~g}$. The supernatant fractions from the lysate were mixed with $2 \times$ SDS sample buffer and boiled for $5 \mathrm{~min}$. Samples were reduced with $5 \% \beta$-mercaptoethanol. For cell surface biotinylation, samples were incubated with $1 \mathrm{mg} / \mathrm{ml}$ sulfo-NHS-LC-biotin (Pierce) in PBS for $30 \mathrm{~min}$ at room temperature, washed with PBS containing $20 \mathrm{mM}$ glycine, and resuspended in $2 \times$ SDS sample buffer.

\section{Western blot analysis}

Each extract containing approximately $20 \mu \mathrm{g}$ protein was subjected to 12 or $15 \%$ polyacrylamide gel electrophoresis, and transferred onto polyvinylidene difluoride (PVDF) membranes (Bio-Rad). Membranes were blocked in TBS-T (TBS: $50 \mathrm{mM}$ Tris-HCl, pH7.5, $150 \mathrm{mM} \mathrm{NaCl}$ and $0.1 \%$ Tween-20) containing $5 \%$ nonfat dry milk for 1 $\mathrm{h}$ at room temperature, and hybridized for $1 \mathrm{~h}$ with primary antibodies, followed by three washes for $10 \mathrm{~min}$ with TBS-T. Bound IgG was detected for $1 \mathrm{~h}$ with alkaline phosphatase-conjugated secondary antibodies (Jackson ImmunoResearch Laboratories). After further washing, alkaline phosphatase activity was detected with NBT/BCIP (Promega Biotech). All primary antibodies were used at 2 $\mu \mathrm{g} / \mathrm{ml}$ dilution. 


\section{Immunofluorescence}

Paraffin sections of mouse testis (Novagen) were deparaffinized using xylene, rehydrated through a graded series of $100 \%, 95 \%, 80 \%$, and $70 \%$ ethanol, and incubated in $3 \%$ hydrogen peroxide in methanol to quench endogenous peroxidase activity. Tissue sections were heated in a microwave oven for $15 \mathrm{~min}$ in $10 \mathrm{mM}$ citrate solution $(\mathrm{pH}$ $6)$ for antigen retrieval. The antibodies for control were pre-treated with the corresponding antigens at $4{ }^{\circ} \mathrm{C}$ for 2 hrs. After blocking with 5\% normal goat serum for 30 min, sections were incubated with the primary antibodies (1:1000 dilution) at room temperature for $1 \mathrm{~h}$, washed three times for 5 min with PBS, and incubated with the Rhodamine Red $^{\mathrm{TM}}$-X goat anti-rabbit IgG (1:1000 in PBS; Molecular Probes). Sections were stained with Hoechst 33342 dye (Sigma), and observed for fluorescent signals under the microscope. Mouse cauda epididymal sperm were fixed on slide glass in $4 \%$ paraformaldehyde and permeabilized with $0.1 \%$ Triton X-100 in PBS at room temperature for $15 \mathrm{~min}$. After extensive washing with PBS, sperm were incubated with normal goat serum at room temperature for $30 \mathrm{~min}$ and then exposed to the primary antibody (1:1000) in PBS at room temperature for $1 \mathrm{~h}$. Sperm were washed three times in PBS and incubated at room temperature with Rhodamine Red $^{\mathrm{TM}}$-X goat anti-rabbit IgG (1:1000 in PBS; Molecular Probes) for $30 \mathrm{~min}$. After washing three times in PBS, sperm fluorescence was observed under a microscope (DMLB; Leica Microsystems).

\section{Authors' contributions}

EC, JL and JO performed classification and selection of genes in the UniGene library. EC, IP, CH and CY carried out the Northern blot and RT-PCR analysis. EC performed the protein analysis. BNC, DHK, EME and CC conceived and directed the project. EC and CC designed the study and drafted the manuscript. All authors read and approved the final manuscript.

\section{Acknowledgements}

This was supported by the Korea Research Foundation Grant (KRF2005004I-C00380) and in part by the Intramural Research Program, NIH, National Institute of Environmental Health Sciences.

\section{References}

I. Eddy EM: 'Chauvinist genes' of male germ cells: gene expression during mouse spermatogenesis. Reprod Fertil Dev 1995, 7(4):695-704.

2. Eddy EM: Regulation of gene expression during spermatogenesis. Semin Cell Dev Biol 1998, 9(4):451-457.

3. Eddy EM: Male germ cell gene expression. Recent Prog Horm Res 2002, 57:103-128.

4. Almstrup K, Nielsen JE, Hansen MA, Tanaka M, Skakkebaek NE, Leffers $\mathrm{H}$ : Analysis of cell-type-specific gene expression during mouse spermatogenesis. Biol Reprod 2004, 70(6): I75I-I76I.

5. Ellis PJ, Furlong RA, Wilson A, Morris S, Carter D, Oliver G, Print C, Burgoyne PS, Loveland KL, Affara NA: Modulation of the mouse testis transcriptome during postnatal development and in selected models of male infertility. Mol Hum Reprod 2004, I0(4):27|-28I.
6. Fujii T, Tamura K, Masai K, Tanaka H, Nishimune $Y$, Nojima H: Use of stepwise subtraction to comprehensively isolate mouse genes whose transcription is up-regulated during spermiogenesis. EMBO Rep 2002, 3(4):367-372.

7. Guo R, Yu Z, Guan J, Ge Y, Ma J, Li S, Wang S, Xue S, Han D: Stagespecific and tissue-specific expression characteristics of differentially expressed genes during mouse spermatogenesis. Mol Reprod Dev 2004, 67(3):264-272.

8. Rossi P, Dolci S, Sette C, Capolunghi F, Pellegrini M, Loiarro M, Di Agostino S, Paronetto MP, Grimaldi P, Merico D, Martegani E, Geremia R: Analysis of the gene expression profile of mouse male meiotic germ cells. Gene Expr Patterns 2004, 4(3):267-28I.

9. Schultz N, Hamra FK, Garbers DL: A multitude of genes expressed solely in meiotic or postmeiotic spermatogenic cells offers a myriad of contraceptive targets. Proc Natl Acad Sci U S A 2003, I00(2I): I 2201-12206.

10. Pontius JU Wagner, L., and Schuler, G.D.: The NCBI Handbook, National Center for Biotechnology Information, Bethesda, MA. 2003.

II. Hong S, Choi I, Woo JM, Oh J, Kim T, Choi E, Kim TW, Jung YK, Kim $\mathrm{DH}$, Sun $\mathrm{CH}$, Yi GS, Eddy EM, Cho C: Identification and integrative analysis of 28 novel genes specifically expressed and developmentally regulated in murine spermatogenic cells. J Biol Chem 2005, 280(9):7685-7693.

12. NCBI [http://www.ncbi.nlm.nih.gov]

13. Bellve AR, Cavicchia JC, Millette CF, O'Brien DA, Bhatnagar YM, Dym $M$ : Spermatogenic cells of the prepuberal mouse. Isolation and morphological characterization. J Cell Biol 1977, 74(I):68-85.

14. Simpson JC, Wellenreuther R, Poustka A, Pepperkok R, Wiemann S: Systematic subcellular localization of novel proteins identified by large-scale cDNA sequencing. EMBO Rep 2000, I (3):287-292.

15. Hofmann MC, Hess RA, Goldberg E, Millan JL: Immortalized germ cells undergo meiosis in vitro. Proc Natl Acad Sci U S A 1994, 9 I ( I 2):5533-5537.

16. Waterston RH, Lindblad-Toh K, Birney E, Rogers J, Abril JF, Agarwal P, Agarwala R, Ainscough R, Alexandersson M, An P, Antonarakis SE, Attwood J, Baertsch R, Bailey J, Barlow K, Beck S, Berry E, Birren B, Bloom T, Bork P, Botcherby M, Bray N, Brent MR, Brown DG, Brown SD, Bult C, Burton J, Butler J, Campbell RD, Carninci P, Cawley S, Chiaromonte F, Chinwalla AT, Church DM, Clamp M, Clee C, Collins FS, Cook LL, Copley RR, Coulson A, Couronne O, Cuff J, Curwen V, Cutts T, Daly $M$, David R, Davies J, Delehaunty KD, Deri J, Dermitzakis ET, Dewey C, Dickens NJ, Diekhans M, Dodge S, Dubchak I, Dunn DM, Eddy SR, Elnitski L, Emes RD, Eswara P, Eyras E, Felsenfeld A, Fewell GA, Flicek P, Foley K, Frankel WN, Fulton LA, Fulton RS, Furey TS, Gage D, Gibbs RA, Glusman G, Gnerre S, Goldman N, Goodstadt L, Grafham D, Graves TA, Green ED, Gregory S, Guigo R, Guyer M, Hardison RC, Haussler D, Hayashizaki Y, Hillier LW, Hinrichs A, Hlavina W, Holzer T, Hsu F, Hua A, Hubbard T, Hunt A, Jackson I, Jaffe DB, Johnson LS, Jones M, Jones TA, Joy A, Kamal M, Karlsson EK, Karolchik D, Kasprzyk A, Kawai J, Keibler E, Kells C, Kent WJ, Kirby A, Kolbe DL, Korf I, Kucherlapati RS, Kulbokas EJ, Kulp D, Landers T, Leger JP, Leonard S, Letunic I, Levine R, Li J, Li M, Lloyd C, Lucas S, Ma B, Maglott DR, Mardis ER, Matthews L, Mauceli E, Mayer JH, McCarthy M, McCombie WR, McLaren S, McLay K, McPherson JD, Meldrim J, Meredith B, Mesirov JP, Miller W, Miner TL, Mongin E, Montgomery KT, Morgan M, Mott R, Mullikin JC, Muzny DM, Nash WE, Nelson JO, Nhan MN, Nicol R, Ning Z, Nusbaum C, O'Connor MJ, Okazaki Y, Oliver K, Overton-Larty E, Pachter L, Parra G, Pepin KH, Peterson J, Pevzner P, Plumb R, Pohl CS, Poliakov A, Ponce TC, Ponting CP, Potter S, Quail M, Reymond A, Roe BA, Roskin KM, Rubin EM, Rust AG, Santos R, Sapojnikov V, Schultz B, Schultz J, Schwartz MS, Schwartz S, Scott C, Seaman S, Searle S, Sharpe T, Sheridan A, Shownkeen R, Sims S, Singer JB, Slater G, Smit A, Smith DR, Spencer B, Stabenau A, Stange-Thomann N, Sugnet C, Suyama M, Tesler G, Thompson J, Torrents D, Trevaskis E, Tromp J, Ucla C, Ureta-Vidal A, Vinson JP, Von Niederhausern AC, Wade CM, Wall M, Weber RJ, Weiss RB, WendI MC, West AP, Wetterstrand K, Wheeler R, Whelan S, Wierzbowski J, Willey D, Williams S, Wilson RK, Winter E, Worley KC, Wyman D, Yang S, Yang SP, Zdobnov EM, Zody MC, Lander ES: Initial sequencing and comparative analysis of the mouse genome. Nature 2002, 420(6915):520-562.

17. Puente XS, Sanchez LM, Overall CM, Lopez-Otin C: Human and mouse proteases: a comparative genomic approach. Nat Rev Genet 2003, 4(7):544-558.

18. Choi I, Oh J, Cho BN, Ahnn J, Jung YK, Han Kim D, Cho C: Characterization and comparative genomic analysis of intronless Adams with testicular gene expression. Genomics 2004, 83(4):636-646.

19. R.A H: Spermatogenesis, Overview. Encyclopedia of Reproduction 1999, 4:539-545.

20. Hansen MA, Nielsen JE, Tanaka M, Almstrup K, Skakkebaek NE, Leffers $\mathrm{H}$ : Identification and expression profiling of 10 novel spermatid expressed CYPT genes. Mol Reprod Dev 2006, 73(5):568-579. 
21. Lobley A, Pierron V, Reynolds L, Allen L, Michalovich D: Identification of human and mouse CatSper 3 and CatSper 4 genes: characterisation of a common interaction domain and evidence for expression in testis. Reprod Biol Endocrinol 2003, I:53.

22. Neesen J, Hartwich T, Brandhorst G, Aumuller G, Glaser B, Burfeind P, Mendoza-Lujambio I: Tep22, a novel testicular expressed gene, is involved in the biogenesis of the acrosome and the midpiece of the sperm tail. Biochem Biophys Res Commun 2002 297(4):737-748.

23. Roy A, Yan W, Burns KH, Matzuk MM: Tektin3 encodes an evolutionarily conserved putative testicular microtubules-related protein expressed preferentially in male germ cells. Mol Reprod Dev 2004, 67(3):295-302.

24. Garbers DL: Ion channels. Swimming with sperm. Nature 200I, 413(6856):579, 581-2.

25. Quill TA, Ren D, Clapham DE, Garbers DL: A voltage-gated ion channel expressed specifically in spermatozoa. Proc Natl Acad Sc U S A 200I, 98(22): | 2527-|253|

26. Ren D, Navarro B, Perez G, Jackson AC, Hsu S, Shi Q, Tilly JL, Clapham $\mathrm{DE}$ : A sperm ion channel required for sperm motility and male fertility. Nature 200I, 4I3(6856):603-609.

27. Jin J, Jin N, Zheng H, Ro S, Tafolla D, Sanders KM, Yan W: Catsper3 and Catsper4 Are Essential for Sperm Hyperactivated Motility and Male Fertility. Biol Reprod 2007, 77(I):37-44.

28. Li HG, Ding XF, Liao AH, Kong XB, Xiong CL. Expression of CatSper family transcripts in the mouse testis during post-natal development and human ejaculated spermatozoa: relationship to sperm motility. Mol Hum Reprod 2007, I3(5):299-306.

29. Iguchi N, Tanaka H, Nakamura Y, Nozaki M, Fujiwara T, Nishimune $Y$ : Cloning and characterization of the human tektin-t gene. Mo Hum Reprod 2002, 8(6):525-530.

30. Matsuyama $\mathrm{T}$, Honda $\mathrm{Y}$, Doiguchi $\mathrm{M}$, lida $\mathrm{H}$ : Molecular cloning of a new member of TEKTIN family, Tektin4, located to the flagella of rat spermatozoa. Mol Reprod Dev 2005, 72(I): I 20-I28.

31. Xu M, Zhou Z, Cheng C, Zhao W, Tang R, Huang Y, Wang W, Xu J, Zeng L, Xie Y, Mao Y: Cloning and characterization of a novel human TEKTINI gene. Int J Biochem Cell Biol 200I, 33(I 2): $1172-1 \mid 82$.

32. lida $\mathrm{H}$, Honda $\mathrm{Y}$, Matsuyama $\mathrm{T}$, Shibata $\mathrm{Y}$, Inai $\mathrm{T}$ : Tektin 4 is located on outer dense fibers, not associated with axonemal tubulins of flagella in rodent spermatozoa. Mol Reprod Dev 2006 73(7):929-936.

33. Wolkowicz MJ, Naaby-Hansen S, Gamble AR, Reddi PP, Flickinger CJ, Herr JC: Tektin BI demonstrates flagellar localization in human sperm. Biol Reprod 2002, 66(I):24l-250.

34. Abou-Haila A, Tulsiani DR: Mammalian sperm acrosome: formation, contents, and function. Arch Biochem Biophys 2000, 379(2): $173-182$

35. Moreno RD, Alvarado CP. The mammalian acrosome as a secre tory lysosome: new and old evidence. Mol Reprod Dev 2006 73(I I): I 430-1434.

36. Honda A, Siruntawineti J, Baba T: Role of acrosomal matrix proteases in sperm-zona pellucida interactions. Hum Reprod Update 2002, 8(5):405-4I2

37. Geissler EN, Ryan MA, Housman DE: The dominant-white spotting (W) locus of the mouse encodes the c-kit proto-oncogene. Cell 1988, 55(I): 185-192.

38. UCSC Genome Informatics resource [http:// www.genome.UCSC.edu/cgi-bin/hgBlat/]

39. Ensembl [http://wwwensemblorg/]

40. PSORTII [http://psort.nibb.ac.jp/form2.html]

4I. CDD [http://www.ncbi.nlm.nih.gov/Structure/cdd/cdd.shtml]

42. Interproscan [http://www.ebi.ac.uk/InterProScan/]

43. PPSearch [http://www.ebi.ac.uk/ppsearch/]

44. SignalP and TMHMM [http://www.cbs.dtu.dk/services/]

45. Goblet [http://goblet.molgen.mpg.de/cgi-bin/goblet/webapp-gob let.cgi]

46. Phelps BM, Koppel DE, Primakoff P, Myles DG: Evidence that proteolysis of the surface is an initial step in the mechanism of formation of sperm cell surface domains. J Cell Biol I 990, I I I (5 Pt I): 1839-1847.

47. Hosokawa M, Shoji M, Kitamura K, Tanaka T, Noce T, Chuma S, Nakatsuji N: Tudor-related proteins TDRDI/MTR-I, TDRD6 and TDRD7/TRAP: domain composition, intracellular localization, and function in male germ cells in mice. Dev Biol 2007 $30 I(I): 38-52$

48. Liu SF, He S, Liu BW, Zhao Y, Wang Z: Cloning and characterization of testis-specific spermatogenesis associated gene homologous to human SPATA4 in rat. Biol Pharm Bull 2004 , 27( I I): $1867-1870$
Publish with Biomed Central and every scientist can read your work free of charge

"BioMed Central will be the most significant development for disseminating the results of biomedical research in our lifetime. "

Sir Paul Nurse, Cancer Research UK

Your research papers will be:

- available free of charge to the entire biomedical community

- peer reviewed and published immediately upon acceptance

- cited in PubMed and archived on PubMed Central

- yours - you keep the copyright

Submit your manuscript here:

http://www.biomedcentral.com/info/publishing_adv.asp
BioMedcentral 